\title{
Dobre praktyki w zakresie edukacji międzykulturowej w Zespole Szkół Technicznych w Cieszynie
}

Streszczenie: Autorka w swym tekście pragnie zaprezentować „dobre praktyki w zakresie edukacji wielokulturowej”, jakie prowadzi w ramach programów europejskich Zespół Szkół Technicznych im. płk. Gwidona Langera w Cieszynie. Nauczyciele i uczniowie szkoły zdobywają i poszerzają doświadczenia w zakresie kształcenia zawodowego w Hiszpanii i na Ukrainie. Zasadnicza tematyka projektu koncentrowała się wokół spraw branżowych odpowiadających na zapotrzebowanie aktualnego rynku pracy. Młodzi ludzie mieli okazję poznać i porównać zawody zdobywane w ich szkołach, zawody swojego miasta, sprawdzić swoje umiejętności zawodowe podczas różnorodnych warsztatów i zajęć praktycznych w różnych pracowniach. Młodzież poprzez międzynarodowe praktyki zawodowe zapoznaje się również z historią i kulturą danego kraju, a co warto podkreślić, uczy się języków. W artykule Autorka podaje programy, jakie są realizowane w praktykach zagranicznych i zwraca uwagę na edukację wielokulturową obecną w Hiszpanii i na Ukrainie, jak również wskazuje na zadania, jakie pełni edukacja międzykulturowa w wielonarodowym i wielowyznaniowym społeczeństwie tych krajów.

Słowa kluczowe: programy europejskie, szkoła, wielokulturowość, edukacja międzykulturowa

W „Przedmowie” do monografii Karola Mozora Szkolnictwo katolickie w Cieszyńskim Wikariacie Generalnym 1770-1925 Stanisław Piech, historyk i metodolog, napisał: „istnieje w naszym społeczeństwie głęboka potrzeba zajmowania się historią własną. Potrzeba ta pochodzi zapewne $\mathrm{z}$ wielu źródeł i tłumaczy się szeregiem przyczyn. Wyzwala ją nie tylko czysta teoretyczna ciekawość czy skłonność do retrospekcji, do patrzenia w przyszłość. O wiele bardziej płynie ona z nakazu współczesności. Właśnie owo spojrzenie w przyszłość dopomaga nam w przeżywaniu współczesności” (2002, s. 7). Tak też należy spojrzeć na Śląsk Cieszyński. Jest on obszarem wielokulturowym o licznych powiązaniach kulturowych i cywilizacyjnych. Społeczność 
tego regionu cechuje historycznie ukształtowana otwartość wobec tradycji europejskiej, a także silne poczucie tożsamości lokalnej i regionalnej.

Społeczności z pokolenia na pokolenie zachowują poczucie swej kulturowej tożsamości. W rozwoju kultury niezastąpione miejsce zajmuje szkolnictwo, które uczy i wychowuje młodzież oraz poznaje wartości ponadczasowe. W ten proces wpisuje się Zespół Szkół Technicznych im. płk. Gwidona Langera, w skład którego wchodzi Technikum Mechaniczno-Elektryczne nr 3 i Szkoła Branżowa 1 Stopnia nr 2.

Zespół Szkól Technicznych powstał na bazie połączenia - 3 września 2007 roku - dwóch placówek Zespołu Szkół Mechaniczno-Elektrycznych i Zespołu Szkól Ponadgimnazjalnych ${ }^{1}$. W placówce uczniowie zdobywają kwalifikacje w zawodach: technik mechatronik, technik mechanik, technik elektryk, technik chłodnictwa i klimatyzacji, technik urządzeń i energetyki odnawialnej i technik usług fryzjerskich. W Zasadniczej Szkole Zawodowej, a teraz także w Szkole Branżowej uczniowie kształcą się w zawodach: elektryk, fryzjer, mechanik pojazdów samochodowych, kierowca mechanik czy w klasach wielozawodowych.

Młodzież „cieszyńskiego Langera”, oprócz realizacji podstawy programowej oraz zdobywania kwalifikacji w zawodzie i uzyskiwania coraz to lepszych wyników na maturze, równocześnie angażuje się w różnego rodzaju działania międzynarodowe czego efektem jest wzbogacenie młodych techników o bogactwo wielokulturowe.

Od 2010 roku szkoła uczestniczy w unijnych programach edukacyjnych: Leonardo da Vinci i Erasmus Plus (2013), dzięki którym szkoła może zdobywać i poszerzać doświadczenia w zakresie kształcenia zawodowego w Hiszpanii, Bułgarii czy Turcji. Młodzież poprzez międzynarodowe praktyki zawodowe zapoznaje się również z historią i kulturą danego kraju, a jednocześnie nauczyciele i młodzież nawiązują między sobą przyjaźnie.

Rok 2012 to początek współpracy z Kolegium Technicznym w Zborowie w Ukrainie. Szkoła podpisała również Umowy Patronackie z Uczelniami Wyższymi: z Wydziałem Budowy Maszyn i Informatyki Akademii Techniczno-Humanistycznej w Bielsku-Białej (25 luty 2015) i z Wydziałem Informatyki i Nauki o Materiałach Uniwersytetu Śląskiego w Katowicach (18 czerwiec 2015). Patronat ten ma na celu podniesienie jakości kształcenia i przygotowania młodzieży do podjęcia studiów wyższych.

1 O historii Zespołu Szkół Technicznych w Cieszynie zob. E. Augustyniak, E Jucha, A. Nawrat, S. Tomiczek, red. (2012). 
Ważnym wydarzeniem dla szkoły był dzień 2 września 2013 roku, kiedy to nastąpiło uroczyste nadanie Zespołowi Szkół Technicznych w Cieszynie imienia pułkownika Gwidona Karola Langera (Kronika szkolna, 2013). Wybór patrona był podyktowany szacunkiem dla dokonań technicznych oraz niezłomnej postawy pułkownika w służbie Ojczyźnie. Langer ${ }^{2}$ jeszcze przed wybuchem II wojny światowej dowodził zespołem, który dokonał złamania szyfru Enigmy, co przyczyniło się do zwycięstwa aliantów. Patron szkoły jest dla młodzieży, jak i dla nauczycieli paradygmatem edukacji technicznej.

Niewątpliwie szkoła w pierwszym swoim znaczeniu wskazuje na wykształcenie. Jednakże byłoby błędem kształcić człowieka, nie wychowując

2 Postać Gwidona Langera została zaprezentowana przez Marka Grajka, jednego z najznakomitszych badaczy historii złamania Enigmy i kryptologa, Marka Grajka. Czytelnik dowiaduje się z niej, że Gwidon Langer „urodził się 2 września 1894 roku w Żylinie na terenie dzisiejszej Słowacji. [...]. Młode lata spędził w Cieszynie, z którego wywodziła się jego rodzina [...]. W latach 1911-1914, był studentem Terezjańskiej Akademii Wojskowej w Wiedniu. [...] W czasie I wojny światowej, był oficerem 16 Pułku Piechoty Landwehry. [...]. W okresie od 4 czerwca 1916 roku do 2 grudnia 1918 roku, Langer przebywał w rosyjskiej niewoli. Po ucieczce z sowieckiego obozu jenieckiego, wrócił do służby w Wojsku Polskim. W dniu 24 stycznia 1922 roku, został on mianowany II oficerem sztabu w Dowództwie 1 Dywizji Górskiej w Białej. Dnia 3 maja 1922 roku został zweryfikowany w stopniu kapitana ze starszeństwem w korpusie oficerów piechoty. Już dnia 23 października 1923 roku, został on przydzielony do Wyższej Szkoły Wojennej w Warszawie, w charakterze słuchacza V Kursu Normalnego. Z dniem 1 grudnia 1924 roku, awansował na majora ze starszeństwem. W niedługim czasie, został kierownikiem Biura Szyfrów. Pełniąc służbę sztabową pozostawał oficerem nadetatowym 4 Pułku Strzelców Podhalańskich W 1932 roku, pod jego kierownictwem kryptolodzy Marian Rejewski, Jerzy Różycki i Henryk Zygalski, złamali szyfry niemieckiej maszyny szyfrującej Enigma. W lipcu 1939 roku, przekazał on dane na temat kodów Enigmy aliantom, dzięki czemu uzyskali oni narzędzie, które w istotny sposób przyczyniło się do ich zwycięstwa, w okresie II wojny światowej. [...].Po kampanii wrześniowej 1939 roku, Gwidon Langer kierował ekipą kryptologów we Francji, a po jej kapitulacji podjął współpracę z wywiadem brytyjskim. Po zajęciu Francji przez Niemców, podjął próbę przejścia do Madrytu. Został on jednak aresztowany przez Niemców. Aresztowanie było wynikiem zdrady przewodnika, który miał przeprowadzić Polaków przez Pireneje. Do końca wojny, pułkownik był więziony w Niemczech, [...]. Po wyzwoleniu wyjechał do Londynu, gdzie w 1947 roku rozpoczął pracę dla polskiego radiowywiadu. W tym samym roku został przeniesiony do rezerwy i wyjechał do miejscowości Kinross w Szkocji, gdzie 30 marca 1948 roku zmarł i został pochowany w niedalekim Perth, [...] (2010, passim); W dniu 1 grudnia 2010 roku jego prochy ekshumowano i pochowano 10 grudnia na Cmentarzu Komunalnym w rodzinnym Cieszynie (zsf/Is/, 2010). 
go: formować jego umysł, zapełniać go pojęciami, wzorami, tezami, wiadomościami i umiejętnościami, a równocześnie żywego człowieka zostawić odłogiem. Tradycja humanistyczna, każe nam zawsze patrzeć na człowieka jako na całość. Wszystko to co zapełnia jego umysł, musi go jednocześnie formować: formować jego serce, jego wolę, jego charakter - po prostu formować jego człowieczeństwo. Edukacja, którą prowadzi Zespół Szkół Technicznych opiera się na trzech filarach, trzech aspektach: poznawczym, kształcącym i praktycznym (wychowawczym). Tym aspektom towarzyszą m.in. Umowy Patronackie i programy Unii Europejskiej w dziedzinie edukacji i szkoleń młodzieży. Stąd bodźcem do napisania niniejszego tekstu dotyczącego tematu Dobre praktyki w zakresie edukacji wielokulturowej w Zespole Szkót Technicznych $w$ Cieszynie jest prowadzona od 2012 roku edukacja międzykulturowa realizowana w ramach programów europejskich przez Zespół Szkół Technicznych im. płk. Gwidona Langera w Cieszynie.

Kierując się aplikacją wybitnego pedagoga - Tadeusza Lewowickiego edukacja ta może stać się zatem praktyką oświatową naszej szkoły, bowiem odwołuje się „do wspólnotowych i uniwersalnych wartości, a przy tym jest wyobrażalna w poczynaniach dydaktycznych i wychowawczych. Wydaje się też pozytywną, konstruktywną odpowiedzią na ważne wyzwania wobec społeczeństw współczesnej Europy" (2000, s.

\section{Wymiana międzynarodowa z Kolegium w Zborowie (Ukraina)}

Współpraca z Kolegium Technicznym w Zborowie została zapoczątkowana w 2012 roku dzięki wsparciu prezesa ogniska Związku Nauczycielstwa Polskiego w Cieszynie. W październiku 2012 roku grupa nauczycieli z Zespołu Szkół Technicznych w Cieszynie na czele z dyrektorem szkoły udała się na Ukrainę do Zborowa w celu ustalenia zasad współpracy i podpisania porozumienia. W grudniu tego samego roku nastąpiła rewizyta, podczas której goście z Ukrainy przyjechali do Cieszyna, aby uczestniczyć w obchodach „100-lecia Zespołu Szkół Technicznych”. W listopadzie 2013 roku młodzież ZST wraz z opiekunami brała udział w polsko-ukraińskiej konferencji pt. „Polska i Ukraina w historycznym wymiarze". Spotkanie odbyło się w Zborowie i trwało 4 dni. W programie znalazły się wystąpienia uczniów z Polski oraz z Ukrainy na temat:

- Ukraina i Polska: wspólna spuścizna, wspólna historia, wspólna przyszłość,

- Historyczne i kulturowe konteksty relacji polsko-ukraińskich, 
- Zamki Galicji - zapomniani świadkowie historii,

- Perła architektury - zamek w Zbarażu,

- Ruch spółdzielczy w powiecie zborowskim w warunkach Polski międzywojennej, Adam Mickiewicz i Ukraina,

- Polityka kulturalno-oświatowa Polski i Ukrainy w stosunku do mniejszości narodowych.

Oprócz wspólnych wystąpień i prezentacji młodzi ludzie mieli możliwość zobaczenia na własne oczy średniowiecznych zamków. Większość zamków lwowskich było przywłaszczonych i rozbudowanych przez polskich magnatów, którzy wywodzili się przeważnie z ukraińskiej szlachty. Na ziemi lwowskiej opieką nad zamkami w Olesku, Podhorcach i Złoczowie zajmuje się Lwowska Galeria Sztuki. Ponadto młodzież miała okazję wspólnie biesiadować podczas kolacji u rodzin ukraińskich, gdzie próbowała lokalnych potraw i smakołyków oraz podziwiała regionalne wyroby przeważnie wykonywane ręcznie. Uczniowie odwiedzili także zborowską parafię greckokatolicką p.w. Współczesnych Męczenników Narodu Ukraińskiego, gdzie zapoznali się z kulturą i doktryną tego Kościoła. W kwietniu 2014 roku ukraińska młodzież przyjechała do Polski z rewizytą, żeby uczestniczyć w konferencji na temat systemu edukacji w szkolnictwie zawodowym w Polsce i na Ukrainie.

Jednak nie tylko zagadnienia związane ze szkolnictwem przyświecały tej wizycie, ale także młodzi ludzie mieli możliwość zobaczenia najciekawszych miejsc Śląska Cieszyńskiego, posmakować regionalnej kuchni oraz poznać naszą tradycję i kulturę. Młodzież ukraińska zapoznała się również kulturą międzywyznaniową, obecną na Śląsku Cieszyńskim, bowiem jest to największy w Polsce obszar zamieszkiwany przez protestantów. Po tym spotkaniu ze względu na sytuację polityczną w Ukrainie współpracę ograniczono do kontaktów za pomocą komunikatorów społecznościowych.

Dopiero rok 2017 przyniósł znaczący przełom w kontaktach obu szkół. Dzięki Fundacji „Możesz Wiedzieć Więcej” działającej przy Zespole Szkół Technicznych w Cieszynie, młodzież z obu szkół mogła przystąpić do wspólnego projektu ogłoszonego przez Polsko-Ukraińską Radę Wymiany Młodzieżyª W związku z tym, że obie grupy młodzieży wywodzą się ze szkół technicznych, główna tematyka projektu koncentrowała się wokół zawodów wykonywanych dawniej i dziś. Młodzi ludzie mieli okazję poznać i porównać zawody zdobywane w ich szkołach, zawody swojego miasta, dawne zawody oraz sprawdzić

3 Zob. Działalność Fundacji „Możesz widzieć więcej”. W: Archiwum Zespołu Szkół Technicznych w Cieszynie. 
swoje umiejętności zawodowe podczas różnorodnych warsztatów i zajęć praktycznych w różnych pracowniach zawodowych. W ramach integracji uczestnicy przygotowywali samodzielnie wspólną kolację, prezentując proste dania kuchni polskiej i ukraińskiej. Ważnym aspektem działań w tym projekcie było włączenie się społeczności lokalnej w ich realizację. Plan tego projektu zawierał:

- prezentację pracowni szkolnych ZST przygotowaną przez młodzież szkolną pod kierunkiem nauczycieli przedmiotów zawodowych oraz przygotowanie i zorganizowanie warsztatów dla uczestników projektu w pracowniach zawodowych,

- prezentację zanikających zawodów przez lokalnych rzemieślników, np. drukarza,

- poczęstunek dla uczestników projektu przygotowywany przez rodziców uczniów.

Efektem wspólnych działań była sesja zdjęciowa, podczas której powstały zdjęcia zawodów wykonywanych dawniej i współcześnie; a finalnie wykorzystane do wystawy fotograficznej, która zaprezentowana została nie tylko w budynku Zespołu Szkół Technicznych w Cieszynie, ale także w Starostwie Powiatowym w Cieszynie oraz w Cechu Rzemieślników i Przedsiębiorców w Cieszynie. Ponadto nakręcony został film prezentujący etapy działań uczestników projektu oraz ich efekty. Uczniowie podczas wizyty stworzyli swój słowniczek podstawowych zwrotów polsko-ukraińskich, który pomagał im w skutecznej komunikacji podczas realizacji projektu, a w przyszłości może posłużyć uczestnikom kolejnych przedsięwzięć. Zbudowali dwa proste kolektory słoneczne, prowadzili stronę internetową projektu oraz fanpage.

Dzięki działaniu takim projektom powoli przełamywane zostają stereotypy kulturowe, a młodzi ludzie stają się bardziej otwarci na nowe kultury i wyzwania, co stanowi istotną zaletę we współczesnym świecie. Udział w projekcie ubogaca młodzież polską i ukraińską zarówno pod względem edukacji zawodowej, jak i komunikacji międzykulturowej. Obserwując kilkuletnią współpracę między naszą szkołą a szkołą w Zborowie można postawić tezę, że poprzez współpracę i wymianę w ramach projektów budowane są pozytywne relacje. Młode pokolenia Polaków i Ukraińców pragną „kształtować swą tożsamość na wartościach umożliwiających im integrację" (Korczyński i Świdzińska, 2017, s. 114).

\section{Staże zagraniczne w Hiszpanii}

Zespół Szkół Technicznych im. płk. Gwidona Langera w Cieszynie, podobnie jak inne szkoły techniczne w Polsce, realizuje reformę kształcenia zawodo- 
wego powiązaną z wprowadzeniem zunifikowanego europejskiego systemu kwalifikacji zawodowych - The European Qualifications Framework, EQF4. System ten promuje mobilność pracowników i uczniów między krajami oraz ułatwiając ich uczenie się przez całe życie. Europejskie ramy kwalifikacji mają na celu powiązanie krajowych systemów kwalifikacji różnych krajów ze wspólnymi europejskimi ramami odniesienia. Szkoła wchodząc w realizację tego programu pragnie zapoznać się z poziomami kwalifikacji różnych krajów i różnych systemów edukacji i szkoleń. W związku z tym, szkoła dąży do podnoszenia jakości kształcenia, poszukuje takich rozwiązań, które pozwolą wyposażyć uczniów w wiedzę powiązaną ściśle z umiejętnościami praktycznymi oraz takie doświadczenia, które uczynią ich konkurencyjnymi na rynkach pracy, także tych europejskich.

W związku z transgranicznym położeniem Cieszyna ważną potrzebą szkoły jest kształcenie uczniów mobilnych, otwartych na odmienność kulturową i językową, którzy będą atrakcyjnymi pracownikami dla zagranicznego pracodawcy. Ważną potrzebą szkoły jest wzrost umiejętności związanych z przygotowaniem, zarządzaniem projektami, które umożliwiają placówce dalszy rozwój i podnoszenie jakości kształcenia. Udział w projektach współfinansowanych m.in. ze środków Unii Europejskiej stanowi źródło rozwoju infrastruktury szkoły, podnoszenie kwalifikacji kadry, a przez udział w dedykowanych uczniom formach wsparcia podnosi jakość kształcenia.

Placówka od 2014 roku uczestniczyła w trzech programach Erasmus $+^{5}$ obejmujących element akcji 1 zatytułowanej „Mobilność osób” skierowanych w ramach kształcenia zawodowego do uczniów i nauczycieli przedmiotów zawodowych. Tytuły projektów zmieniały się w poszczególnych latach:

4 Europejskie ramy kwalifikacji zostały formalnie przyjęte przez Parlament Europejski i Radę w kwietniu 2008 roku. Mają one „zastosowanie do wszystkich rodzajów edukacji, szkoleń i kwalifikacji, od edukacji szkolnej po edukację akademicką, zawodową i zawodową. Takie podejście przenosi uwagę z tradycyjnego systemu, który kładzie nacisk na nakłady edukacyjne, takie jak długość doświadczenia edukacyjnego lub rodzaj instytucji. Zachęca także do uczenia się przez całe życie poprzez promowanie walidacji uczenia się pozaformalnego i nieformalnego" (Europejskie, 2017).

5 Zespół Szkół Technicznych w Cieszynie uczestniczy w programie Erasmus +, który jest programem Unii Europejskiej w dziedzinie edukacji, szkoleń, młodzieży i sportu na lata 2014-2020. Struktura tego programu obejmuje następujące elementy: Akcja 1. Mobilność edukacyjna; Akcja 2. Współpraca na rzecz innowacji i wymiany dobrych praktyk; Akcja 3. Wsparcie w reformowaniu polityk; program Jean Monnet; Sport (O programie Erasmus+, 2017). 
- 2014 - Europejskie staże lekarstwem na bezrobocie wśród młodych techników,

- 2015 - Europejskie praktyki trampoliną do sukcesu młodych techników,

- 2017 - Kompetencje zawodowe bez granic.

Głównym celem projektu jest zdobywanie przez uczniów nowych doświadczeń zawodowych w odmiennych warunkach kulturowych, a także zapoznanie się z nowymi rozwiązaniami technologicznymi w dziedzinach, w których zdobywają zawód. Poza tym projekt zakłada szereg innych celów, których realizacja warunkuje podniesienie kompetencji jego uczestników. Do najważniejszych możemy zaliczyć:

- poznanie nowych technologii skorelowanych z programem nauczania i zdobywanymi kwalifikacjami zawodowymi,

- doświadczenie zawodowe zdobyte w odmiennych warunkach kulturowych pozwoli uczniom podnieść swoją samoocenę oraz lepiej radzić sobie ze stresem,

- w związku z charakterem realizowanych w ramach projektu zadań uczniowie nabywają także, tak potrzebnej na rynku pracy umiejętności współdziałania w zespole,

- to także poznawanie kultury i obyczajów, a przede wszystkim nabywanie umiejętności swobodnego posługiwania się językiem, zwłaszcza w środowisku pracy,

- wielojęzyczność - mimo że językiem projektu jest język angielski, uczniowie zarówno przed wyjazdem, jak i podczas pobytu w Hiszpanii uczestniczyli w kursie języka hiszpańskiego,

- bezpośrednio mieli okazję podnosić swoje kompetencje językowe w naturalnych sytuacjach komunikacyjnych takich, jak: lotnisko, muzeum, restauracja czy autobus,

- celem projektu była także promocja wartości europejskich, m.in. tolerancji na odmienność w zakresie światopoglądu, narodowości, respektowanie praw obywatelskich,

- udział w projekcie wpłynął również na wzrost samodzielności, większą obowiązkowość, zdyscyplinowanie, wzrost poczucia odpowiedzialności za wykonywane zadania.

Od 2014 roku w programie Erasmus+ uczestniczyło w sumie 88 uczniów we wszystkich zawodach będących w ofercie szkoły.

Istotnym elementem w czasie trwania projektu był program językowo-kulturowy. Uczniowie uczestniczyli w kursie języka hiszpańskiego oraz zajęciach na temat tradycji i kultury Hiszpanii, a w szczególności Andaluzji, dla- 
tego że praktyki odbywały się zawsze w Sewilii. Uczniowie zwiedzali miasto z uwzględnieniem najważniejszych zabytków, specyfiki kultury i specjalności kulinarnych. Projekt odpowiada na podstawową potrzebę placówki, jaką jest zwiększenie konkurencyjności przyszłych absolwentów na rynku pracy. Projekt jest również adekwatną odpowiedzią na potrzebę zmiany stereotypów kulturowych i pogłębienie procesów integracji europejskiej.

\section{Zakończenie}

Umowy Patronackie i programy Unii Europejskiej w dziedzinie edukacji i szkoleń młodzieży, jakie prowadzi Zespół Szkół Technicznych im. płk. Gwidona Langera w Cieszynie to nie tylko realizowanie deskryptorów i wskaźników stosowanych do zarządzania jakością zarówno na poziomie systemu kształcenia i szkolenia zawodowego, ale równocześnie koncentrują się wokół kwestii wielokulturowości, relacji między przedstawicielami kultur i religii oraz społeczno-kulturowej tożsamości. Nauczyciele i młodzież korzystają z dorobku różnych społeczności i uczestniczą w dialogu „zawodowym” i kulturowym. Wymiana wzajemna pozwala na kształcenie uczniów mobilnych, otwartych na odmienność kulturową i językową. Jednocześnie wzajemna wymiana umożliwia pogłębianie wrażliwości i szacunku dla różnic kulturowych, co jest „nieodzowne w procesie wychowania i kształcenia" (Ogrodzka-Mazur, 2012, s. 214). W tym kontekście realizowana jest przez naszą szkołę edukacja międzykulturowa, a jak zauważa Jerzy Nikitorowicz podejmuje ona „trud zauważenia człowieka, jego niezbywalnych praw, jednak w kontekście wzajemnego doświadczania siebie, uznawania i szanowania różnic, wzajemnego zrozumienia i porozumienia, prowadzenia trudnego, ustawicznego dialogu" (2017, s. 27). Posiada to niewątpliwy wpływ na mentalne otwarcie się na innych oraz na nowe sposoby myślenia i zachowania. Powyższa "praktyka oświatowa” staje się modelem, który winien sprzyjać „poznawaniu, rozumieniu i - co jest najważniejsze akceptowaniu różnych kultur i tworzących je podmiotów" (Ogrodzka-Mazur i Szafrańska, 2017, s. 11) oraz w zdobywaniu wiedzy technicznej, umiejętności i kompetencji. Jednocześnie nasza szkoła pragnie w swym programie edukacji międzykulturowej realizować cnoty obywatelskie, takie jak: „więź z własną społecznością, społeczeństwem, krajem, ojczyzną, przy jednoczesnym poszanowaniu innych społeczności"(Nikitorowicz, 2017, s. 32) ${ }^{6}$.

6 Treści dotyczące cnót obywatelskich wygłosił Władysław Bartoszewski podczas wykładu inauguracyjnego w Uniwersytecie Warszawskim. 
W ramach realizowania programów europejskich młode pokolenie Polaków, Ukraińców i Białorusinów, jak stwierdził Jerzy Nikitorowicz, „chce kształtować swoją tożsamość na wartościach umożliwiających im integrację, współpracę, wymianę w ramach projektów edukacyjnych i kulturalnych" (2000, s. 122). Obecne pokolenie pragnie żyć bez wojen, wrogości, zapiekłych i nieracjonalnych konfliktów wywoływanych zróżnicowaniem kulturowym, religijnym i wieloma innymi - jakże często bezsensownymi i wyniszczającymi - podziałami między ludźmi. Pierwszorzędną powinnością nauczycieli i wychowawców jest pomaganie ludziom w wydobywaniu z nich tego wszystkiego, co w nich najlepsze. Edukacja międzykulturowa jest w tym szlachetnym dziele ważnym sposobem postępowania i drogą spełniania się nadziei na lepszy świat, i „służy szczęśliwemu życiu ludzi” (Lewowicki, 2012, s. 37).

Sprawy dotyczące edukacji, a w tym edukacji międzykulturowej, odgrywają istotną rolę w kreowaniu myślenia humanistycznego i technicznego, jakie podejmuje Zespół Szkół Technicznych im. płk. Gwidona Langera w Cieszynie.

\section{Bibliografia}

Archiwum Zespołu Szkól Technicznych w Cieszynie. Syg. ZST/2014/ .

Działalność Fundacji „Możesz widzieć więcej”. W: Archiwum Zespołu Szkół Technicznych w Cieszynie.

Europejskie ramy kwalifikacji. https://en. wikipedia. org/ wiki/ European_ Qualifications_Framework (6.12.2017).

Grajek, M. 2010. Putkownik Gwido Karol Langer 1894-1948. Warszawa:

Urząd do Spraw Kombatantów i Osób Represjonowanych.

Korczyński, M. i Świdzińska, A. 2017. Wrażliwość międzykulturowa studentów z pogranicza polsko-ukraińskiego. Edukacja Międzykulturowa. 1, ss. 113-129.

Kronika szkolna Zespołu Szkół Technicznych w Cieszynie (2013).

Krótka historia Zespołu szkót Technicznych. 2012. W: Augustyniak, E., Jucha, E., Nawrat, A. i Tomiczek, S., red. 100 lat edukacji na ulicy Frysztackiej. Cieszyn: Zespół Szkół Technicznych.

Lewowicki, T. 2000. W poszukiwaniu modelu edukacji międzykulturowej. W: Lewowicki T., Ogrodzka-Mazur E. i Szczurek-Boruta A. red. Edukacja międzykulturowa $w$ Polsce $i$ na świecie. Katowice: UŚ. 
Lewowicki, T. 2012. Edukacja międzykulturowa - bilans otwarcia 2012. Edukacja Międzykulturowa. 1, ss. 15-46.

Nikitorowicz, J. 2000. Młodzież pogranicza Kulturowego pogranicza Polski, Białorusi i Ukrainy wobec integracji europejskiej. Białystok: Wydawnictwo Uniwersyteckie „Trans Humana”.

Nikitorowicz, J. 2017. Edukacja międzykulturowa w procesie przeciwstawiania się dehumanizacji i infrahumanizacji. Edukacja Międzykulturowa. 1, ss. $19-35$.

O programie Erasmus+. W: http://erasmusplus.org.pl/o-programie/ (10.12.2017).

Ogrodzka-Mazur, E. 2012. Edukacja międzykulturowa. Recenzja: Pogranicze. Studia Społeczne, t. XVII, cz. 1, red. Nikitorowicz, J., Sadowski, A. i Misiejuk, D. Edukacja Międzykulturowa.1, ss. 212-215.

Ogrodzka-Mazur E. i Szafrańska A. 2017. Wprowadzenie. Edukacja Międzykulturowa. 1, ss. 11-15.

Piech, S. 2002. Przedmowa. W: Mozor, K. Szkolnictwo katolickie w Cieszyńskim Wikariacie Generalnym 1770-1925. Kraków: PAT.

szf/Is/. 2010. Ptk Gwido Langer spoczał na cmentarzu w Cieszynie. W: http:// dzieje.pl /aktualnosci/plk-gwido-langer-spoczal-na-cmentarzu-w-cieszynie.

\section{Good practices concerning intercultural education in The Complex of Technical Schools in Cieszyn}

Abstract: The author wants to present "good practices in the area of multicultural education" which are led within European programmes by Zespół Szkół Technicznych im. płk. Gwidona Langera in Cieszyn (Colonel Gwido Langer Complex of Technical Schools in Cieszyn). The teachers and the students of that school gain and develop experience in terms of professional training in Spain and Ukraine. The basic subject of the project concentrated around professional issues responding to the demands of a current labor market. Young people had an opportunity to meet and compare professions taught in the schools, jobs typical for their towns and cities, check their professional skills while participating in diverse workshops and the training in various laboratories. The youth through international apprenticeships also get to know history and culture of different countries and, what is worth emphasizing, they learn foreign languages.

In the article the author mentions the programmes which are implemented over foreign professional training and she pays attention to multicultural educa- 
tion present in both Spain and Ukraine, as well as she points to the tasks performed by international education in multinational and multireligious societies of those countries.

Keywords: European programmes, school, multiculturalism, intercultural education 